Metallophysics and Advanced Technologies

Металофіз. новітні технол.

Metallofiz. Noveishie Tekhnol.

2020, vol. 42 , No. 5 , pp. $717-730$

https://doi.org/10.15407/mfint.42.05.0717

Reprints available directly from the publisher
(C) 2020 G. V. Kurdyumov Institute for Metal Physics, National Academy of Sciences of Ukraine Published by license under

the G. V. Kurdyumov Institute for Metal PhysicsN.A.S. of Ukraine Publishers imprint. Printed in Ukraine.

PACS numbers: 43.20. $+\mathrm{g}, 68.08 .-\mathrm{p}, 68.35 . \mathrm{Md}, 68.35 . \mathrm{Np}, 68.60 . \mathrm{Bs}, 71.20 . \mathrm{Nr}$

\title{
Prediction of Adhesion Energy Terms in Metal/Ceramic Systems by Using Acoustic Parameters
}

\author{
K. Kamli, Z. Hadef, A. Gacem*, and N. Houaidji ${ }^{* *}$ \\ University of 20 August 1955, Faculty of Sciences, Department of Physics, \\ 26 Road El Hadaiek, 21000 Skikda, Algeria \\ "University of 20 August 1955, Faculty of Technology, Department of Technology, \\ 26 Road El Hadaiek, 21000 Skikda, Algeria \\ ${ }^{* *}$ Badji Mokhtar University, Faculty of Sciences, Department of Physics, \\ Laboratory of Semiconductors, \\ B.P. 12, Sidi Amar, CP 23000 Annaba, Algeria
}

In this paper, we predict the adhesion energy terms in metal/ceramic systems by using acoustic parameters of these combinations. Different approaches are used. Semiempirical relations are deduced for all systems. As shown, in all cases, the adhesion energy $W_{\text {ad }}$ increases linearly with Rayleigh velocity of ceramic substrate $V_{R C}$. It takes the form $W_{\text {ad }}=0.07 V_{R C}+C$, where the first term of this equation represents the van der Waals contribution to $W_{\mathrm{ad}}$, which only depends on $V_{R C}$. The second term represents the equilibrium chemical bonds contribution ( $W_{\text {chem-equil }}$ ) and strongly depends on the systems combination as well as on the energy gap of the ceramics substrate. Moreover, the $W_{\text {chem-equil }}$ energy is higher for small bandgap ceramic materials due to substantial charge carriers' density inside ceramic crystal and, consequently, ease and height electron transfer through the metal/ceramic interface. In this case, the $W_{\text {chem-equil }}$ is essentially depends on Rayleigh velocity $V_{R M}$ of deposited metal. For large bandgap ceramic materials, there are practically no free charges inside ceramic crystal. In this case, the electrons' transfer cannot be taking place and, as a result, the $W_{\text {chem-equil }}$ contribution is negligible. The importance of obtained relation lies in its universality and applicability to all investigated systems.

Key words: adhesion, metal/ceramic interfaces, energy gap, acoustic parameters.

Corresponding author: Zakaria Hadef

E-mail: zaki_hd2013@yahoo.fr

Citation: K. Kamli, Z. Hadef, A. Gacem, and N. Houaidji, Prediction of Adhesion

Energy Terms in Metal/Ceramic Systems by Using Acoustic Parameters, Metallofiz. Noveishie Tekhnol., 42, No. 5: 717-730 (2020), DOI: 10.15407/mfint.42.05.0717. 
Дану роботу присвячено прогнозуванню складових енергії адгезії в системах метал/кераміка з використанням акустичних параметрів цих комбінацій та різних підходів. Для всіх систем одержуються напівемпіричні залежності. Показано, що у всіх випадках енергія адгезії $W_{\text {ad }}$ лінійно збільшується зі швидкістю Релея $V_{R C}$ керамічної підкладинки і приймає вигляд $W_{\text {ad }}=0,07 V_{R C}+C$. Перший член цього рівняння представляє внесок Ван-дер-Ваальса в $W_{\text {ad }}$, він залежить тільки від $V_{R C}$. Другий член представляє внесок у $W_{\text {ad }}$ рівноважних хімічних зв'язків $\left(W_{\text {chem-equil }}\right)$ і сильно залежить від комбінації складових системи, а також від енергетичної щілини керамічної підкладинки. Крім того, енергія $W_{\text {chem-equil }} \epsilon$ більшою для керамічних матеріалів з малою шириною забороненої зони через значну густину вільних носіїв заряду всередині керамічного кристалу та, відповідно, полегшене перенесення електронів через межу розділу метал/кераміка. В цьому випадку $W_{\text {chem-equil }}$ істотно залежить від швидкості Релея $V_{R M}$ нанесеного металу. Для керамічних матеріалів з великими забороненими зонами в середині керамічного кристалу практично відсутні вільні носії заряду. В цьому випадку перенесення електронів не буде i, як результат, внесок $W_{\text {chem-equil }}$ буде незначним. Важливість одержаної залежності полягає в їі універсальності і застосовності до всіх досліджених систем.

Ключові слова: адгезія, межа розділу метал/кераміка, заборонена зона, акустичні параметри.

Данная работа посвящена определению составляющих энергии адгезии в системах металл/керамика с использованием акустических параметров этих комбинаций и разных подходов. Для всех систем получаются полуэмпирические зависимости. Показано, что во всех случаях энергия адгезии $W_{\text {ad }}$ линейно увеличивается со скоростью Рэлея $V_{R C}$ керамической подложки и принимает вид $W_{\text {ad }}=0,07 V_{R C}+C$. Первый член этого уравнения представляет вклад Ван-дер-Ваальса в $W_{\text {ad }}$, он зависит только от $V_{R C}$. Второй член представляет вклад в $W_{\text {ad }}$ равновесных химических связей $\left(W_{\text {chem-equil }}\right)$ и сильно зависит от комбинации составляющих системы, а также от энергетической щели керамической подложки. Кроме того, энергия $W_{\text {chem-equil }}$ больше для керамических материалов с малой шириной запрещённой зоны из-за значительной плотности свободных носителей заряда внутри керамического кристалла и, следовательно, облегчённого переноса электронов через границу раздела металл/керамика. В этом случае $W_{\text {chem-equil }}$ существенно зависит от скорости Рэлея $V_{R M}$ нанесённого металла. Для керамических материалов с большими запрещёнными зонами внутри керамического кристалла практически нет свободных носителей заряда. В этом случае отсутствует перенос электронов и, как результат, вклад $W_{\text {chem-equil }}$ будет незначительным. Важность полученной зависимости заключается в её универсальности и применимости ко всем исследованным системам.

Ключевые слова: адгезия, граница раздела металл/керамика, запрещённая зона, акустические параметры.

(Received July 4, 2019; in final version, January 27, 2020) 


\section{INTRODUCTION}

Metalized ceramics have a crucial uses in several modern technological applications such as electrical devices, metal films on ceramic substrates, metal-ceramic bonding, ceramic-metal matrix composites etc. However, the coating of ceramic surfaces can affect most of the properties of the interface. Therefore, the investigation of interfacial phenomena between metals and ceramic substrates is of great importance not only in technological applications but also in fundamental understanding of physical behaviour of the adhesion between two different materials as far as their electrical structures and physiochemical properties are concerned. In fact, at the interface of a metal/ceramic system, adhesion occurs when the atoms or molecules of the two contacting surfaces approach each other so closely that attractive forces between approaching atoms (or molecules) bond them together. The strength of the bond depends on the size of the atoms, the distance between them, and the presence or absence of contaminant matter on the surface [1]. Hence, the strength or weakness of bonds is the key factor to determine the interface stability: good adhesion, welded adhesion, perfect bonding, weak bonding smooth interface etc. The metal/ceramic contact is characterized by the adhesion energy $W_{\text {ad }}$, which is the work per unit area of the interface needed to separate reversibly a metal/ceramic interface [2]. This physicochemical parameter is given by Young-Dupré equation relating surface tension of molten metal above melting temperature, $\gamma_{L V}$, and measured equilibrium contact angle $\theta$ formed between deposited liquid metal and its ceramic substrate [2]:

$$
W_{\text {ad }}=\gamma_{L V}(1+\cos \theta) .
$$

It represent in generally the sum of all interfacial interactions between two surfaces [3]:

$$
W_{\text {ad }}=W_{\text {non-equil }}+W_{\text {equil }},
$$

where $W_{\text {non-equil }}$ and $W_{\text {equil }}$ represents non-equilibrium and equilibrium contributions respectively of interfacial interactions. The first term does not exist in the absence of chemical reactions, and the second term corresponds to non-reactive metals/ceramic systems [3], this later expressed by

$$
W_{\text {equil }}=W_{V D W}+W_{\text {chem-equil }},
$$

where $W_{V D W}$ represents van der Waals interactions and $W_{\text {chem-equil }}$ represents chemical equilibrium interactions accompanied by formation of 
these chemical bonds between two contact phases. It is important to note that these interfacial bonds rested without rupture contrary in non-equilibrium systems [2]. Van der Waals energy in metal/ceramic systems can be numerically estimated by considering the dispersion interaction between a pair of atoms:

$$
W_{V D W}=n \frac{3 \alpha_{M} \alpha_{C}}{2 R^{6}} \frac{I_{M} I_{C}}{I_{M}+I_{C}},
$$

where $\alpha_{M}$ and $\alpha_{C}$ are the polarizability volumes of metal and ceramic, $I_{M}$ and $I_{C}$ are the first ionization potentials of metal and ceramic atoms, respectively, $R$ is the distance between centres of the interacting atoms.

At the interface zone, the surface acoustic wave (SAW) propagation, which depends on elastic properties of solid substrates, is greatly affected: the response would be different depending on the weakness or strength of bonds due to impedance mismatching [4]. Hence, in this context, we investigate the dependences of adhesion energy on acoustic parameters, in particular SAW velocities, for many metal/ceramic systems.

\section{METHODOLOGY AND MATERIALS}

\subsection{Calculation Procedure}

In this work, two approaches are adopted: the first one is scanning acoustic microscope, SAM, approach $[5,6]$ and the second is one parameter approach, OPA [7].

The SAM approach consists of theoretical determination of these velocities from the so-called acoustic materials signatures, this analogue signal received by transducer and focused by the position of the acoustic lens at the sample against the distance $z$, under an incidence angle with the reflected ones [5,6]. The $V(z)$ is the result of the several interferences of all the leaky wave modes, such as leaky surface acoustic wave (SAW), leaky pseudo-SAW, leaky surface-skimming compression wave, leaky Lamb wave, and harmonic waves. However, only the velocity of leaky SAWs has been extracted from the $V(z)$ curves in microanalysis mode proposed by Sheppard and Wilson [8], who derived the following expression:

$$
V(z)=\int_{0}^{\theta_{\max }} P^{2}(\theta) R(\theta) \exp \left(2 j k_{0} z \cos \theta\right) \sin \theta \cos \theta d \theta .
$$

Here $P(\theta)$ is the pupil function, $k_{0}=2 \pi / \lambda$ is the wave number in the coupling liquid, $j=\sqrt{-1}, \theta$ is the half-opening angle of the lens, and $R(\theta)$ is the reflection coefficient that is given by

$$
R(\theta)=\left(Z_{\mathrm{sol}}-Z_{\mathrm{liq}}\right) /\left(Z_{\mathrm{sol}}+Z_{\mathrm{liq}}\right),
$$


where $Z_{\text {sol }}$ and $Z_{\text {liq }}$ are solid and liquid acoustic impedances, respectively. They satisfy the following relationships:

$$
\begin{gathered}
Z_{\text {sol }}=\cos ^{2} 2 \theta_{L}+\sin ^{2} 2 \theta_{T}, \\
Z_{\text {liq }}=\rho_{\text {liq }} V_{\text {liq }} / \cos \theta_{\text {liq }}
\end{gathered}
$$

with $Z_{L}$ and $Z_{T}$ being longitudinal and transverse acoustic impedances, respectively, $\theta_{T}$ is the critical angle at which transverse mode is excited, $\rho_{\text {liq }}$ is the liquid density, and $V_{\text {liq }}$ is wave velocity in this liquid.

The steps of the SAM approach, consist of determining SAW velocities of different modes, calculating acoustic materials signatures and deducing SAW velocities via fast Fourier transform (FFT) treatment of periodic $V(z)$ signatures. The details of these steps can be found elsewhere [9-11].

One parameter approach consists of determining SAW velocities (longitudinal $V_{L}$, transverse $V_{T}$, and Rayleigh $V_{R}$ ) from materials density $(\rho)$ and elastic constants such Young's modulus $(E)$ is deduced according to the well-established conventional relation and vice versa, i.e.

$$
E=\rho V_{T}^{2}\left(3 \rho V_{L}^{2}-4 \rho V_{T}^{2}\right) /\left(\rho V_{L}^{2}+\rho V_{T}^{2}\right) .
$$

The former consists of using the simplified familiar relations of elastic constants into simple relations. Hence, $E$ is expressed in terms of the velocity of just one single mode $\left(V_{L}, V_{T}, V_{R}\right)$, as we recently reported [7]:

$$
E=2.99 \rho V_{R}^{2}=0.575 \rho V_{L}^{2}=2.586 \rho V_{T}^{2} .
$$

\subsection{Materials and Simulation Conditions}

In this study, we consider several metals ( $\mathrm{Au}, \mathrm{Cu}, \mathrm{Sn}, \mathrm{Ga}$, and $\mathrm{Ag}$ ) on a great number of ceramic substrates $\left(\mathrm{AlN}, \mathrm{Al}_{2} \mathrm{O}_{3}, \mathrm{BN}, \mathrm{CoO}, \mathrm{Er}_{2} \mathrm{O}_{3}, \mathrm{Ho}_{2} \mathrm{O}_{3}\right.$, $\mathrm{Lu}_{2} \mathrm{O}_{3}, \mathrm{MgO}, \mathrm{NiO}, \mathrm{SiC}, \mathrm{SiO}_{2}, \mathrm{TiC}, \mathrm{TiO}, \mathrm{TiO}_{2}, \mathrm{Ti}_{2} \mathrm{O}_{3}, \mathrm{Y}_{2} \mathrm{O}_{3}, \mathrm{Yb}_{2} \mathrm{O}_{3}, \mathrm{ZnO}$, and $\left.\mathrm{Zr}_{2} \mathrm{O}_{3}\right)$. The characteristics of all ceramic materials-energy gap $\left(E_{g}\right)$ [12], density $\left(\rho_{C}\right)$, and Young's modulus $\left(E_{C}\right)$ [13] are listed in Table 1.

The simulation conditions are those usually used experimentally in the case of a reflexion scanning acoustic microscope (SAM) [9-11]: a half opening angle of the lens of $50^{\circ}$, an operating frequency $f=145$ $\mathrm{MHz}$ and water as a coupling liquid whose wave velocity $V_{\text {liq }}$ equal to $1500 \mathrm{~m} / \mathrm{s}$ and density $\rho_{\text {liq }}$ equal to $1000 \mathrm{~kg} / \mathrm{m}^{3}$.

\section{RESULTS AND DISCUSSIONS}

\subsection{Acoustic Signatures and Treatment}

In the one parameter approach, we used simplified relations (10) and 
TABLE 1. Characteristics of investigated ceramic materials: energy gap $\left(E_{g}\right)$, density $\left(\rho_{C}\right)$, and Young's modulus $\left(E_{C}\right)$ as well as the determined Raleigh $V_{R C}$.

\begin{tabular}{|c|c|c|c|c|c|c|c|}
\hline \multirow{2}{*}{$\begin{array}{c}\text { Ceramic } \\
\text { sub- } \\
\text { strate }\end{array}$} & \multirow{2}{*}{$\begin{array}{c}E_{g}, \\
\mathrm{eV} \\
{[12]}\end{array}$} & \multirow{2}{*}{$\begin{array}{c}\rho_{C}, \\
\mathrm{~kg} / \mathrm{m}^{3} \\
{[13]}\end{array}$} & \multirow{2}{*}{$\begin{array}{l}E_{C}, \\
\text { GPa } \\
{[13]}\end{array}$} & \multirow{2}{*}{$\begin{array}{c}\text { SAM } \\
\text { approach } \\
V_{R C / S A M}, \\
\mathrm{~m} / \mathrm{s}\end{array}$} & \multicolumn{3}{|c|}{ One parameter approach } \\
\hline & & & & & $\begin{array}{l}V_{L C}, \\
\mathrm{~m} / \mathrm{s}\end{array}$ & $\begin{array}{l}V_{T C}, \\
\mathrm{~m} / \mathrm{s}\end{array}$ & $\begin{array}{c}V_{R C / O P A}, \\
\mathrm{~m} / \mathrm{s}\end{array}$ \\
\hline AlN & 5.6 & 3260 & 318 & 5616 & 11367 & 6169 & 5712 \\
\hline $\mathrm{Al}_{2} \mathrm{O}_{3}$ & 7.1 & 3980 & 330 & 5650 & 11437 & 6207 & 5747 \\
\hline $\mathrm{BN}$ & 8.1 & 3487 & 34 & 1834 & 3594 & 1950 & 1806 \\
\hline $\mathrm{CoO}$ & 0.5 & 9423 & 281 & 2871 & 5725 & 3107 & 2877 \\
\hline $\mathrm{Er}_{2} \mathrm{O}_{3}$ & 3.2 & 8651 & 179 & 2633 & 5236 & 2841 & 2631 \\
\hline $\mathrm{Ho}_{2} \mathrm{O}_{3}$ & 3.9 & 8414 & 175 & 2639 & 5248 & 2848 & 2637 \\
\hline $\mathrm{Lu}_{2} \mathrm{O}_{3}$ & 4.0 & 9423 & 204 & 2691 & 5355 & 2906 & 2691 \\
\hline $\mathrm{MgO}$ & 7.3 & 3580 & 310 & 5297 & 10710 & 5813 & 5382 \\
\hline $\mathrm{NiO}$ & 2.5 & 6670 & 420 & 6205 & 12579 & 6827 & 6321 \\
\hline $\mathrm{SiC}$ & 3.3 & 3210 & 393 & 6714 & 13626 & 7395 & 6847 \\
\hline $\mathrm{SiO}_{2}$ & 7.9 & 2600 & 75 & 3678 & 7383 & 4007 & 3710 \\
\hline $\mathrm{TiC}$ & 0.3 & 4940 & 400 & 5370 & 10861 & 5895 & 5458 \\
\hline $\mathrm{TiO}$ & 0.0 & 4950 & 387 & 3960 & 7964 & 4322 & 4002 \\
\hline $\mathrm{TiO}_{2}$ & 3.1 & 4230 & 315 & 4917 & 9932 & 5390 & 4991 \\
\hline $\mathrm{Ti}_{2} \mathrm{O}_{3}$ & 0.1 & 4468 & 118 & 4411 & 8891 & 4825 & 4468 \\
\hline $\mathrm{Y}_{2} \mathrm{O}_{3}$ & 5.5 & 5030 & 176 & 3398 & 6808 & 3695 & 3421 \\
\hline $\mathrm{Yb}_{2} \mathrm{O}_{3}$ & 1.4 & 9293 & 229 & 2677 & 5325 & 2890 & 2676 \\
\hline $\mathrm{ZnO}$ & 3.4 & 5606 & 125 & 2730 & 5435 & 2949 & 2731 \\
\hline $\mathrm{ZrO}_{2}$ & 8.0 & 5600 & 244 & 3781 & 7596 & 4122 & 3817 \\
\hline
\end{tabular}

some published data [13] of $\rho$ and $E$ to determine SAW velocities; the results are grouped in Table 1 . The obtained data of $V_{L}$ and $V_{T}$ are then used in the SAM approach, i.e. they are inserted in relations (5) and (6) to deduce the $V(z)$ curves of all substrate materials.

Typical $V(z)$ results are illustrated in Fig. 1 for four bulk substrates $\mathrm{ZnO}(a), \mathrm{Y}_{2} \mathrm{O}_{3}(b), \mathrm{TiO}(c)$, and $\mathrm{AlN}(d)$. It should be noted that similar curves were obtained for all other ceramic substrates. It is clear that both curves exhibit oscillatory behaviour due to constructive and destructive interferences between axial beams and the reflected leaky waves in the reflection SAM configuration.

The spacing between two successive maxima or successive minima, known as $\Delta z$, differs from one material. This oscillatory behaviour is 
treated via fast Fourier transform analysis. The obtained spectra are displayed in Fig. 1. It is well established that under normal operating conditions of a SAM, the most dominating mode is the Rayleigh one. Hence, the principal peak obtained in FFT spectra (Fig. 1) represents such a mode form, which the Rayleigh velocity $V_{R}$ is deduced according the following formula [5]:

$$
V_{R}=V_{\text {liq }}\left[1-\left(V_{\text {liq }} /(2 f \Delta z)\right)^{2}\right]^{-1 / 2} \text {. }
$$

The results, thus obtained, are regrouped in Table 1 for Rayleigh velocities of all investigated ceramics. These values are close to those obtained via the one parameter approach.

\subsection{Determination of Adhesion Energy Terms}

\subsubsection{Correlation between Adhesion Energy and SAW Velocities}

The variations of work of adhesion on Rayleigh velocity for different ceramic substrate $\left(V_{R C}\right)$ in contact with different nonreactive metals $(\mathrm{Au}, \mathrm{Cu}, \mathrm{Sn}, \mathrm{Ga}$, and $\mathrm{Ag})$ are investigated. In this investigation, we consider some published data on work of adhesion for different met-

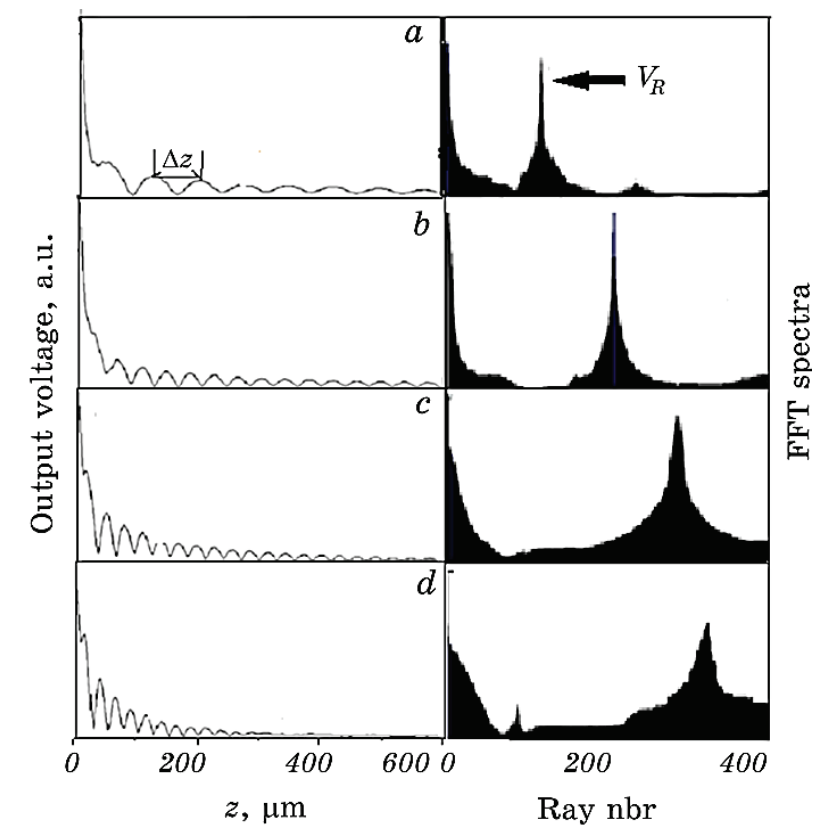

Fig. 1. Acoustic signatures and their corresponding FFT spectra for ceramic substrates: $\mathrm{ZnO}(a), \mathrm{Y}_{2} \mathrm{O}_{3}(b), \mathrm{TiO}(c)$, and $\mathrm{AlN}(d)$. 
als/ceramics systems $[2,3,14-26]$. The obtained results are presented below.

To investigate the effects of the work of adhesion for different metal/ceramic systems on corresponding ceramic Rayleigh velocity, we first consider gold/ceramic combinations, the obtained results are illustrated in Fig. 2.

In order to generalize the above observations obtained with gold/ceramic substrates systems and to put into evidence the results reproducibility, we considered several other nonreactive metals deposited on different ceramic substrates, i.e. ( $\mathrm{Cu}, \mathrm{Sn}, \mathrm{Ga}$, and $\mathrm{Ag})$.

The obtained results are illustrated in Fig. 3 in terms of work of adhesion as a function of ceramic Rayleigh velocities in contact with several nonreactive metals ( $\mathrm{Ag}, \mathrm{Au}, \mathrm{Cu}, \mathrm{Ga}$, and $\mathrm{Sn})$. All the curves show the same behaviour: the work of adhesion increases linearly with increasing $V_{R C}$. However, we distinguish two sets of linear dependences that are regrouped according to the band gap energy of the ceramic substrate, as discussed below.

\subsubsection{Quantification of the Results}

The dependence of $W_{\text {ad }}$ on $V_{R C}(\mathrm{Au})$ is quantified via curve fitting, (lines in Figs. 2 and 3). We distinguish two parallel dependences for gold/ceramic substrate systems for higher energy values (upper curve) the linear variation is found to be of the form:

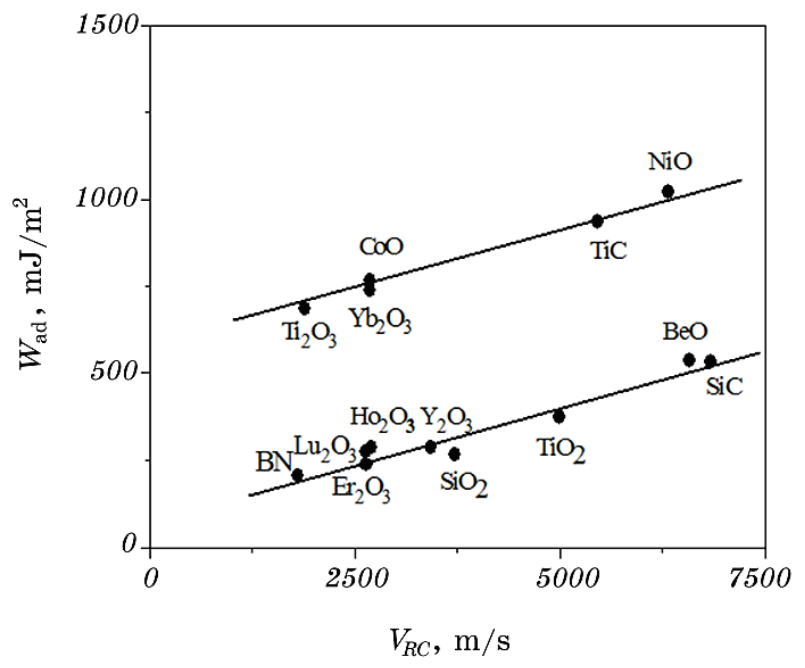

Fig. 2. Work of adhesion as function of calculated Rayleigh velocities of different ceramic substrates in contact with gold; the lines are the best fit. 


$$
W_{\text {ad }}(\mathrm{Au})=0.07 V_{R C}+553 .
$$

Whereas, for small energy values (lower curve), the linear dependence is found to be of the form:

$$
W_{\text {ad }}(\mathrm{Au})=0.07 V_{R C}+76 .
$$

Moreover, it should be noted that the same behaviour of two parallel lines is obtained for all metal/ceramic systems. Therefore, all curves have a same slop not only for small energy gap materials but also for large gap ceramics; the general expression takes the form:

$$
\begin{aligned}
& W_{\text {ad }}(\mathrm{Me})=0.07 V_{R C}+C, \\
& W_{\text {ad }}(\mathrm{Me})=0.07 V_{R C}+C^{\prime},
\end{aligned}
$$

where the notation Me represents any given investigated nonreactive liquid metal ( $\mathrm{Ag}, \mathrm{Au}, \mathrm{Cu}, \mathrm{Ga}$, and $\mathrm{Sn}), C$ and $C^{\prime}$ are characteristic constants for each metal/ceramic combination.

The exact corresponding values of characteristic constants $C$ (for small gap ceramic materials) and $C^{\prime}$ (for large gap ceramic materials) of several liquid metal/ceramic systems are giving in the Table 2.

\subsubsection{Prediction of van der Waals Contribution}

The similar dependence (with the same slope equal to $0.07 V_{R C}$ ) is indicative of the existence of the same mechanism responsible for this behaviour. However, the existence of two parallel dependences for every

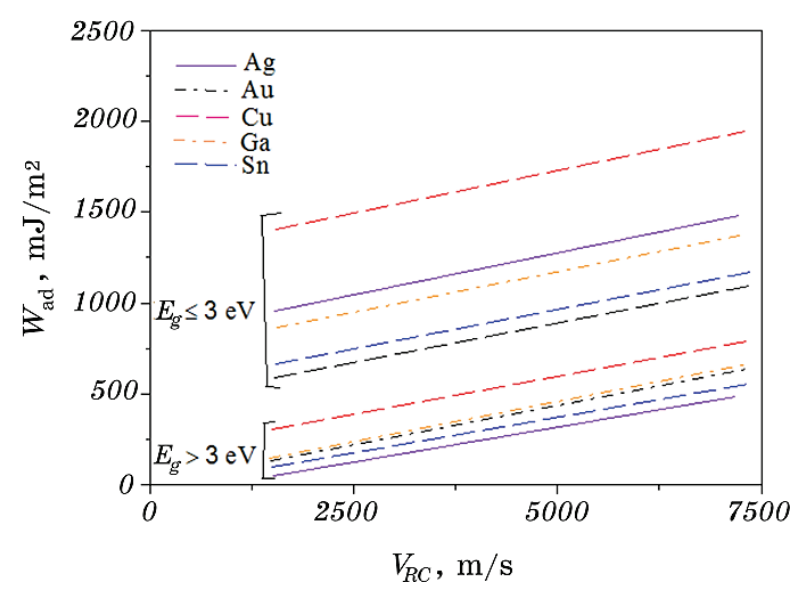

Fig. 3. Work of adhesion as function of calculated Rayleigh velocities of different ceramic substrates in contact with several metals $(\mathrm{Ag}, \mathrm{Au}, \mathrm{Cu}, \mathrm{Ga}$, and Sn); the lines are the best fit. 
TABLE 2. Values of $C$ and $C^{\prime}$ for different liquid metal/ceramic systems.

\begin{tabular}{ccc}
\hline Metals & $C, \mathrm{~mJ} / \mathrm{m}^{2}$ & $C^{\prime}, \mathrm{mJ} / \mathrm{m}^{2}$ \\
\hline $\mathrm{Ag}$ & 991 & 14 \\
$\mathrm{Au}$ & 533 & 76 \\
$\mathrm{Cu}$ & 1309 & 228 \\
$\mathrm{Ga}$ & 863 & 78 \\
$\mathrm{Sn}$ & 602 & 37 \\
\hline
\end{tabular}

system is due to the energy band structure of the ceramic materials in particular the energy gap (Table 1). A close analysis of Fig. 3 and the $E_{g}$ column clearly shows that the upper set of curves corresponds to solid ceramic materials with small energy gaps $\left(E_{g} \leq 3 \mathrm{eV}\right)$, whereas the lower ensemble of curves represents ceramic materials with large energy gaps $\left(E_{g}>3 \mathrm{eV}\right)$.

In fact, solid materials with small band gaps behave as conductors $\left(E_{g} \rightarrow 0\right)$ or semiconductors $\left(E_{g} \leq 3 \mathrm{eV}\right)$. In this case, it was reported [27] that the high adhesion energy values of same metal/ceramic systems are associated with high electron density of metals and low band gap energy of solids ceramics. The interfacial adhesion between a metal and a ceramic crystal is assured by the electron transfer [2], it is interesting to define an interfacial propriety represents the minimum energy needed for appearance of a limit number of interfacial bonds responsible for generating of the adhesion between the metal and the ceramic, this energy is caused by van der Waals interaction $\left(W_{V D W}\right)$. The intensity of the electron transfer at small bandgap solid ceramic is increased because of its wealth by the free charges inside and the chemical equilibrium contribution $W_{\text {chem-equil }}$ taking place.

For large bandgaps, there will be practically a small number of free charges inside ceramic crystal. As a result, the chemical equilibrium contribution $W_{\text {chem-equil }}$ to the adhesion energy is negligible. Consequently, the adhesion energy is approximately resulted by from the van der Waals interaction [2].

The van der Waals contribution of adhesion energy rested constant and proportional with Rayleigh velocity of ceramic materials whether it is the band gap energy, for the first time it is determined exactly as follows:

$$
W_{V D W}=0.07 V_{R C} .
$$

The determinate $W_{V D W}$ energy values for different metal/ceramic systems depend directly on the choice of various parameters appearing in Eq. (3). For example, Mc Donald and Eberhart [28] calculated $W_{V D W}$ 
values equal to $500 \pm 150 \mathrm{~mJ} / \mathrm{m}^{2}$ for different metal/alumina systems, that in our model and for the same system we have found $W_{V D W}$ values equal to $396 \mathrm{~mJ} / \mathrm{m}^{2}$. While Naidich [3] found $W_{V D W}$ values of $350 \pm 150$ $\mathrm{mJ} / \mathrm{m}^{2}$ for metal/oxide ceramic systems, this confirms the compatibility between our proposed model and other model of $W_{V D W}$ estimation.

\subsubsection{Prediction of Chemical Equilibrium Contribution}

\subsubsection{Small Gap Ceramic Materials}

The characteristic constant $C$ in Eq. (13a) represents $W_{\text {chem-equil }}$ contribution, this energy is relatively important compared to $W_{V D W}$ energy. It represents another interfacial property responsible for putting the stability and the perfection to the interface between metal and ceramic. The good convergence in $W_{\text {chem-equil }}$ values for a given metal/small gap ceramics could be explained by the fact that for $E_{g}<3 \mathrm{eV}$ here will be a big density of charge carriers inside the ceramic crystal and consequently height electron transfer.

In this work, an analytical approach [29] is adopted to express the relation between experimental sound velocities of liquid metals $(c)$ at the melting temperature and determinate Rayleigh velocity of these metals at solid state $\left(V_{R M}\right)$ by SAM program. Hence, $V_{R M}$ is expressed in terms of $c$, as we recently reported [29]:

$$
V_{R M}=0.674 c \text {. }
$$

The chemical equilibrium energy $W_{\text {chem-equil }}$ of metal/small bandgap ceramic system determinate by Eq. (13a), experimental sound velocities of liquid metals [30], the determinate Rayleigh velocities of bulk metals are summarized in Table 3.

The variations of chemical equilibrium energy on normalized Rayleigh velocity $\left(V_{R M} / z\right)$ for different bulk metals in contact with several small bandgap ceramic materials are investigated, where $z$ is coordination number of each metal atom. In this investigation, we consider Eq. (13a) to determine $W_{\text {chem-equil }}$ and some published works on adhesion energy for different metals/ceramics systems [2, 3, 14-26]. The obtained results are presented below.

The dependence of $W_{\text {chem-equil }}$ on $\left(V_{R M} / z\right)$ is quantified via curve fitting (line in Fig. 4). We distinguish dependence for liquid metal/small bandgap ceramic substrate systems: the linear variation is found to be of the form

$$
W_{\text {chem-equil }}=(1.3 / z) V_{R M} \text {. }
$$

So, the chemical equilibrium contribution to adhesion energy in met- 
TABLE 3. Characteristics of investigated metals: experimental sound velocities of liquid metals $(c)$, determined Raleigh velocity $\left(V_{R M}\right)$, coordination number of each atom of metal $(z)$, and determinate chemical equilibrium energy ( $\left.W_{\text {chem-equil }}\right)$ of metal/small bandgap ceramic system.

\begin{tabular}{c|c|c|c|c}
\hline Metals & $\begin{array}{c}W_{\text {chem-equil }}, \\
\mathrm{mJ} / \mathrm{m}^{2}\end{array}$ & $\begin{array}{c}C, \mathrm{~m} / \mathrm{s} \\
{[30]}\end{array}$ & $\begin{array}{c}V_{R M / S A M}, \\
\mathrm{~m} / \mathrm{s}\end{array}$ & $\begin{array}{c}z \\
{[31]}\end{array}$ \\
\hline $\mathrm{Ag}$ & 991 & 2790 & 1558 & 2 \\
$\mathrm{Al}$ & 1269 & 4561 & 3130 & 3 \\
$\mathrm{Au}$ & 553 & 2568 & 1136 & 3 \\
$\mathrm{Cu}$ & 1309 & 3440 & 2159 & 2 \\
$\mathrm{Co}$ & 1341 & 4031 & 3015 & 3 \\
$\mathrm{Fe}$ & 1276 & 4200 & 3003 & 3 \\
$\mathrm{In}$ & 723 & 2337 & 1575 & 3 \\
$\mathrm{Ni}$ & 1193 & 4047 & 2796 & 3 \\
$\mathrm{Ga}$ & 863 & 2737 & 1845 & 3 \\
$\mathrm{Sn}$ & 602 & 2464 & 1400 & 4 \\
\hline
\end{tabular}

al/ceramic system is related directly to the Rayleigh velocity of metal.

\subsubsection{Large Gap Ceramic Materials}

The discrepancy in $C^{\prime}$ values for a given metal/large gap ceramics could be explained by the fact that for $E_{g}>3 \mathrm{eV}$ here will be a smaller density of free charges inside the ceramic crystal (practically no free charges inside) and consequently the electron transfer at metal/ceramic interfaces cannot be important [2]. As a result, the characteristic constant $C^{\prime}$ values are negligible compared to $W_{V D W}$ energy and/or especially to $W_{\text {chem-equil }}$ energy.

Therefore, the general expression of adhesion energy takes the form:

a) for small gap ceramic materials

$$
W_{\text {ad }}(\mathrm{Me})=0.07 V_{R C}+(1.3 / z) V_{R M},
$$

b) for large gap ceramic materials

$$
W_{\text {ad }}(\mathrm{Me})=0.07 V_{R C}+W_{\text {negl }} .
$$

The importance of the deuced relation lies in its applicability to all investigated metal/ceramic systems. It could be extended, through familiar relations, to other acoustic parameters. Similar results for 


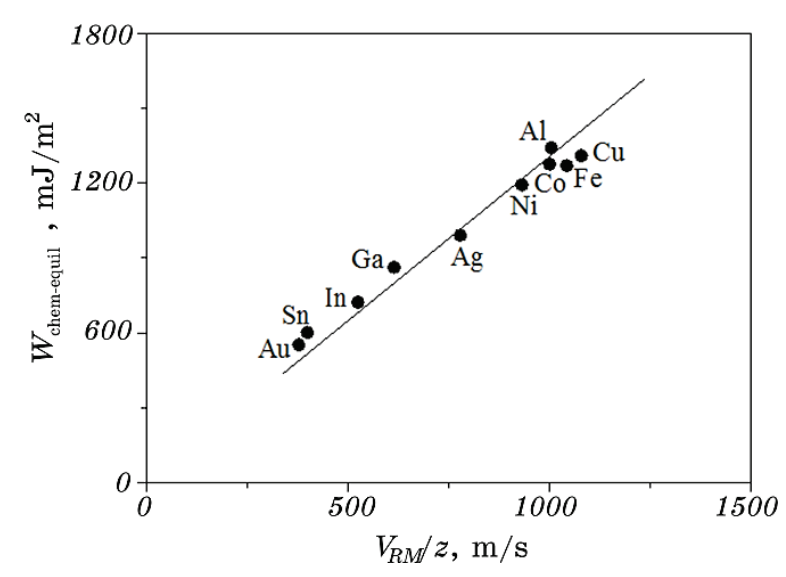

Fig. 4. Chemical equilibrium energy $W_{\text {chem-equil }}$ of metal/small bandgap ceramic system as function of normalized Rayleigh velocities $\left(V_{R M} / z\right)$ of different bulk metals.

longitudinal and transverse velocities were obtained. Moreover, preliminary results for elastic constants (Young's modulus and shear modulus) are very satisfying.

\section{CONCLUSION}

In this work, the adhesion energy terms in metals/ceramic systems was predicted by using acoustic parameters. Acoustic signatures, surface acoustic wave velocities were determined for all cases. It was shown that the adhesion energy increases linearly with Rayleigh velocity of ceramic substrates for all types of ceramics. Van der Waals term of adhesion energy was deduced only depends on Rayleigh velocities of ceramic. On the other hand, the deduced chemical equilibrium term strongly depends on the energy gap of the ceramics materials: it is higher for small bandgap ceramic materials and depends on Rayleigh velocities of metals, for the opposite case it is deduced negligible. The considered universal relations that could be extended to other acoustic or elastic parameters are applicable to all metal/ceramic combinations.

\section{REFERENCES}

1. F. E. Kennedy, Encyclopaedia of Physics (Eds. Lerner and Trigg) (Weinheim: Wiley-VCH: 2005).

2. J. G. Li, Mater. Lett., 22, Nos. 3-4: 169 (1995).

3. Yu. V. Naidich, The Progr. Surf. Membr. Sci., 14: 353 (1981).

4. I. A. Viktorov, Rayleigh and Lamb Waves (New York: Plenum Press: 1967).

5. J. Kushibiki and N. Chubachi, IEEE Trans. Sonics and Ultrasonics, SU32: 189 
(1985).

6. R. G. Maev, Acoustic Microscopy: Fundamentals and Applications (Berlin: Wiley-VCH: 2008).

7. M. Doghmane, F. Hadjoub, A. Doghmane, and Z. Hadjoub, Mater. Letters, 61, No. 3: 813 (2007).

8. C. G. R. Sheppard and T. Wilson, Appl. Phys. Let., 38, No. 11: 884 (1981).

9. Z. Hadef, A. Doghmane, and K. Kamli, Metallofiz. Noveishie Tekhnol., 40, No. 7: 955 (2018).

10. P. V. Zinin, Handbook of Elastic Properties of Solids, Liquids and Gases (Eds. M. Levy, H. Bass, and R. Stern) (New York: Academic Press: 2001).

11. A. Briggs, Advances in Acoustic Microscopy (New York: Plenum Press: 1995), vol. 1.

12. W. H. Strehlow and E. L. Cook, J. Phys. Chem. Ref. Data 2, 2, No. 1: 163 (1973).

13. G. A. D. Briggs and O. V. Kolosov, Acoustic Microscopy (Oxford: Oxford Univ. Press: 2010).

14. N. Eustathopoulos, N. Sobczak, A. Passerone, and K. Nogi, Mater. Sci., 40: $2271(2005)$.

15. Yu. V. Naidich, V. S. Zhuravlev, and N. I. Frumina, Mater. Sci., 25: 1895 (1990).

16. J.-G. Li, Scripta Metallurgica et Materialia, 30, Iss. 3: 337 (1994).

17. N. Y. Taranets and Yu. V. Naidich, Powder Metall. Met. Ceramics, 35, Nos. 5-6: 74 (1996).

18. G. W. Liu, M. L. Muolo, F. Valenza, and A. Passerone, Ceram. Inter., 36, No. 4: 1177 (2010).

19 M. Kida, M. Bahraini, J. M. Molina, L. Weber, and A. Mortensen, Mater. Sci. Eng. A, 495, Nos. 1-2: 197 (2008).

20. Y. Naidich, Current Opinion in Solid State and Materials Science, 9, Iss. 4-5: 161 (2005).

21. J.-G. Li, J.Amer.Ceram.Soc., 75, No. 11: 3118 (1992).

22. J. G. Li and H. Hausner, Mater. Let, 11, Nos. 10-12: 355 (1991).

23. J. G. Li, Comp. Interf., 1, No. 1: 37 (1993).

24. J. G. Li and H. Hausner, Mater. Letters, 14329 (1992).

25. D. Chatain, I. Rivollet, and N. Eustathopoulos, J. Chim. Phys., 83: 561 (1986).

26. D. Sotiropoulou and P. Nikolopoulos, J. Mater. Sci., 28: 356 (1993).

27. J. G. Li, Mater. Sci. Let., 11: 903 (1992).

28. J. B. Mc Donald and J. G. Eberhart, Trans. AIME, 233: 512 (1965).

29. Z. Hadef, A. Doghmane, K. Kamli, and Z. Hadjoub, Prog. Phys. Met., 19, No. 2: 168 (2018).

30. S. Blairs, J. Coll. Interf. Sci., 302: 312 (2006).

31. O. Olubosede, O. M. Afolabi, R. S. Fayose, E. O. Oniya, and A. C. Tomiwa, Appl. Phys. Res., 3, No. 2: 171 (2011). 